\title{
Using the Design of Experiment Method to Evaluate Quality of Cuts after Cutting Aluminum Alloy by AWJ
}

Helena Čierna, Miroslava Ťavodová

Faculty of Environmental and Manufacturing Technology, Technical University in Zvolen. Email: cierna@tuzvo.sk

The article deals with the use of the SPC method, specifically the DoE method - Design of Experiment method, during evaluation of a finished area of aluminum allow AlMg3 with an abrasive waterjet (AWJ). Design of experiment utilized a basic model, which presents a process as a change in input factors on an output characteristic. The basis of this method stems from the fact that the output characteristic, which expresses a specific measured qualitative attribute has its variability. We can identify numerous factors that affect the quality of finished area when cutting material with the help of an abrasive waterjet. With the help of statistical methods within quality management, we can determine which factors are important. Four input factors, feed speed, thickness of the material, water pressure and mass flow of the abrasives mass flow, were selected to evaluate an output factor, roughness of surface Ra. With the help of the $2^{4}$ experiment, with the help of software, we can observe and evaluate the importance of these processing factors. Based on results from the experiment one can come to conclusions which will help with finding optimal conditions for achieving the most abrasive surface possible after cutting of aluminum alloy AIMg3, using the AWJ technology.

Keywords: abrasive waterjet, surface quality, DoE, SPC, factor analysis.

\section{References:}

[1] MAŇKOVÁ, Ildikó. Progresívne technológie. Košice: Vienala Košice, 2000. 275 s. ISBN 80-7099-43-4.

[2] VAGASKÁ, Alena. Štatistické riadenie kvality čelne frézovaného povrchu hliníka, http://www.sjf.tuke.sk/transferinovacii/pages/archiv/transfer/14-2009/pdf/084-087.pdf Dostupné na internete (20.08.2013).

[3] HASHISH, Mohamed. Optimalization Factors in Abrasive Waterjet Machining, ASME 1992, Journal of Engineering for Industry, Vol 113, 1991, No.2.

[4] HASHISH, Mohamed. Material properties in Abrasive-Waterjet Machining, ASME 1995, Journal of Engineering for Industry, Vol 117.

[5] ̌TAVODOVÁ, Miroslava; NÁPRSTKOVÁ, Nataša. Hodnocení kvality povrchu materiálu po řezání AWJ, Strojírenská technologie Roč. 17, č.3 (2012), s. 186-192. ISSN 1211-4162.

[6] WANG, J. Abrasive Waterjet Machining of Engineering Materials, Monograph Series, Materials Scienceb Foundations, Volume 19, 200. ISBN 978-0-87849-918-2.

[7] HRABČAKOVÁ, Ivana. Matematické modelovanie vplyvu technologických parametrov na parametre kvality $v$ procese delenia konštrukčnej ocele. Manufacturing Technology, 2010, roč. IX, č.1, s.74-76. ISSN 1335-7972.

[8] CHAO, J. et al. Characteristic of Abrasive Waterjet Generated Surfaces and Effects of Cutting Parameters and Structure Vibration. ASME, Journal of Engineering for Industry, Vol 117, Nov., 1995. 516-525.

[9] MONTGOMERY, D.,C. Design and Analysis of Experiments. 5th edition, Hamilton Printing Company, 2001. ISBN 0-471-31649-0.

[10] http://archiv.ipaslovakia.sk/UserFiles/File/ZL/Prumyslove\%20inzenyrstvi\%20casopis/2010_3_Rie\%c5\%a1eni e\%20probl\%c3\%a9mov\%20met\%c3\%b3dou\%20DoE.pdf, Dostupné na internete (02.09.2013).

[11] KUČEROVÁ, Marta. Stanovenie úrovní vstupných faktorov pri procese popúštania drôtu metódou DoE. http://www.sjf.tuke.sk/transferinovacii/pages/archiv/transfer/23-2012/pdf/159-163.pdf. Dostupné na internete (20.08.2013).

[12] NOVAK, Martin. Surface quality of hardened steels after grinding. Manufacturing Technology, 2011, roč. XI, č. 11. s. 55- 59. ISSN 1213-2489.

[13] HLOH, Sergej; VALÍČEK, Jan. Vplyv faktorov na topografiu povrchov vytvorených hydroabrazívnym delením. Prešov: FVT TU v Košiciach so sídlom v Prešove, 2008. 125 s. ISBN 978-80-553-0091-7. 